\title{
Zhihengliuella aestuarii sp. nov., isolated from tidal flat sediment
}

Correspondence

Chi Nam Seong scnu@scnu.ac.kr

\section{Keun Sik Baik, ${ }^{1}$ Chae Hong Lim, ${ }^{1}$ Seong Chan Park, ${ }^{1}$ Han Na Choe, ${ }^{1}$ Ho Jun Kim, ${ }^{1}$ DuWoon Kim, ${ }^{2}$ Kang Hyun Lee ${ }^{3}$ and Chi Nam Seong ${ }^{1}$}

\author{
${ }^{1}$ Department of Biology, Sunchon National University, Suncheon 540-742, Republic of Korea \\ ${ }^{2}$ Department of Food Science and Technology, Chonnam National University, Gwangju 500-757, \\ Republic of Korea \\ ${ }^{3}$ Biological Resource Center, Korea Research Institute of Bioscience and Biotechnology, \\ 52 Oun-dong, Yuseong, Daejeon 305-333, Republic of Korea
}

The genus Zhihengliuella (family Micrococcaceae) was established by Zhang et al. (2007) and, at the time of writing, contained three species, Zhihengliuella halotolerans (the type species; Zhang et al., 2007), Z. alba (Tang et al., 2009) and ' $Z$. salsuginis' (Chen et al., 2010; this name has not been validly published). Members of the genus have been isolated from saline soil and subterranean brine samples and are Gram-positive, catalase-positive, oxidasenegative, asporogenous, short rod-shaped or coccoid actinobacteria. The diagnostic cell-wall sugar is tyvelose and the peptidoglycan type is $\mathrm{A} 4 \alpha$. In this paper, we present the results of a polyphasic taxonomic study of an isolate from tidal flat sediment in Korea and propose a novel species of the genus Zhihengliuella to accommodate it.

Strain ${\text { DY } 66^{\mathrm{T}}}^{\mathrm{T}}$ was isolated from tidal flat sediment of Deukryang Bay ( $\left.34^{\circ} 42^{\prime} \mathrm{N} 127^{\circ} 10^{\prime} \mathrm{E}\right)$, Republic of Korea, by using the standard dilution plating technique on marine agar (MA; Becton Dickinson), and cultivated at $20{ }^{\circ} \mathrm{C}$ for

The GenBank/EMBL/DDBJ accession number for the 16S rRNA gene sequence of strain DY66 ${ }^{\top}$ is EU939716.

Six supplementary figures are available with the online version of this paper.
7 days. The isolate was routinely cultured on MA and maintained at $-80{ }^{\circ} \mathrm{C}$ as a suspension in marine broth (MB; Becton Dickinson) containing glycerol (20\%, v/v).

Bacterial DNA preparation, PCR amplification and sequencing of the 16S rRNA gene were carried out as described previously (Chun \& Goodfellow, 1995). Identification of phylogenetic neighbours and calculation of pairwise $16 \mathrm{~S}$ rRNA gene sequence similarities were achieved using the EzTaxon server (http://www.eztaxon.org; Chun et al., 2007). Related sequences and the novel sequence were aligned by using CLUSTAL_X (Thompson et al., 1997) and the alignment was refined using PHYDIT (http://plaza.snu.ac.kr/ jchun/ phydit/; Chun, 1995). Phylogenetic analysis was performed by using the computer packages PHYLIP (Felsenstein, 1993) and PAUP* 4.0 (Swofford, 1998). Phylogenetic trees were inferred using maximum-likelihood (Felsenstein, 1993), maximum-parsimony (Fitch, 1971) and neighbour-joining (Saitou \& Nei, 1987) algorithms. Distance matrices for the neighbour-joining method were generated according to the model of Jukes \& Cantor (1969). The robustness of the topology of the phylogenetic trees was evaluated by bootstrap analyses (Felsenstein, 1985) of the neighbour-joining method based on 1000 resamplings. 
Preliminary sequence comparisons with 16S rRNA gene sequences held in GenBank indicated that strain DY66 ${ }^{\mathrm{T}}$ was closely related to the genera Arthrobacter, Citricoccus, Micrococcus and Zhihengliuella. The newly determined sequence was then aligned manually against representatives of the family Micrococcaceae. Strain DY66 ${ }^{\mathrm{T}}$ showed the highest 16S rRNA gene sequence similarity to Arthrobacter pascens DSM $20545^{\mathrm{T}}$ ( $97.0 \%$ sequence similarity) followed by Micrococcus terreus $\mathrm{V}^{\mathrm{M} 1} 1^{\mathrm{T}}$, Arthrobacter woluwensis DSM $10495^{\mathrm{T}}$ and Micrococcus yunnanensis YIM $65004^{\mathrm{T}}$ (each 96.9\%), Arthrobacter globiformis DSM 20124 ${ }^{\mathrm{T}}$ (96.8\%), Zhihengliuella halotolerans YIM $70185^{\mathrm{T}}$, Micrococcus luteus NCTC $2665^{\mathrm{T}}$, Arthrobacter phenanthrenivorans Sphe $3^{\mathrm{T}}$ and Micrococcus antarcticus $\mathrm{T} 2^{\mathrm{T}}$ (each 96.7\%) and Zhihengliuella alba YIM $90734^{\mathrm{T}}$, Arthrobacter crystallopoietes DSM 20117 ${ }^{\mathrm{T}}$, Citricoccus zhacaiensis $\mathrm{FS}^{\mathrm{T}}{ }^{\mathrm{T}}$, Micrococcus lylae DSM $20315^{\mathrm{T}}$ and Micrococcus endophyticus YIM $56238^{\mathrm{T}}$ (each $96.6 \%$ ); the sequence similarity to other members of the genera Arthrobacter, Citricoccus, Micrococcus and Zhihengliuella was below 96.6\%. Phylogenetic analysis based on 16S rRNA gene sequences indicated that strain $\mathrm{DY}^{\mathrm{T}}{ }^{\mathrm{T}}$ belonged to the genus Zhihengliuella (Fig. 1). The tree topologies inferred from the neighbour-joining, maximum-likelihood and maximum-parsimony algorithms were essentially the same (Fig. 1 and Supplementary Figs S1 and S2, available in IJSEM Online).

Growth on various standard bacteriological media was tested by using nutrient agar (NA), tryptic soy agar (TSA) and R2A agar (all from Becton Dickinson) according to the manufacturer's instructions. Cells of strain $\mathrm{DY} 66^{\mathrm{T}}$ grown on TSA containing $2 \% \mathrm{NaCl}$ at $30{ }^{\circ} \mathrm{C}$ for 2 days were used for physiological and biochemical tests. The Gram reaction of cells grown on TSA containing $2 \% \mathrm{NaCl}$ at $30{ }^{\circ} \mathrm{C}$ for 2 days was tested by using the bioMérieux Gram stain kit according to the manufacturer's instructions. The cell life cycle was examined using cultures grown on TSA and in tryptic soy broth (TSB; Becton Dickinson), both containing $2 \% \mathrm{NaCl}$, for up to 2 weeks. Cell morphology was observed using a differential interference microscope (BX50; Olympus) and scanning electron microscope (S4800; Hitachi). Endospore formation was observed with a phase-contrast microscope (TMS-F; Nikon). Motility was examined by observing cells grown in wet mounts using a phase-contrast microscope. Growth at $0-10 \%(\mathrm{w} / \mathrm{v}) \mathrm{NaCl}$ (in increments of $1.0 \%$ ) was investigated in TSB prepared according to the formula of the Becton Dickinson medium

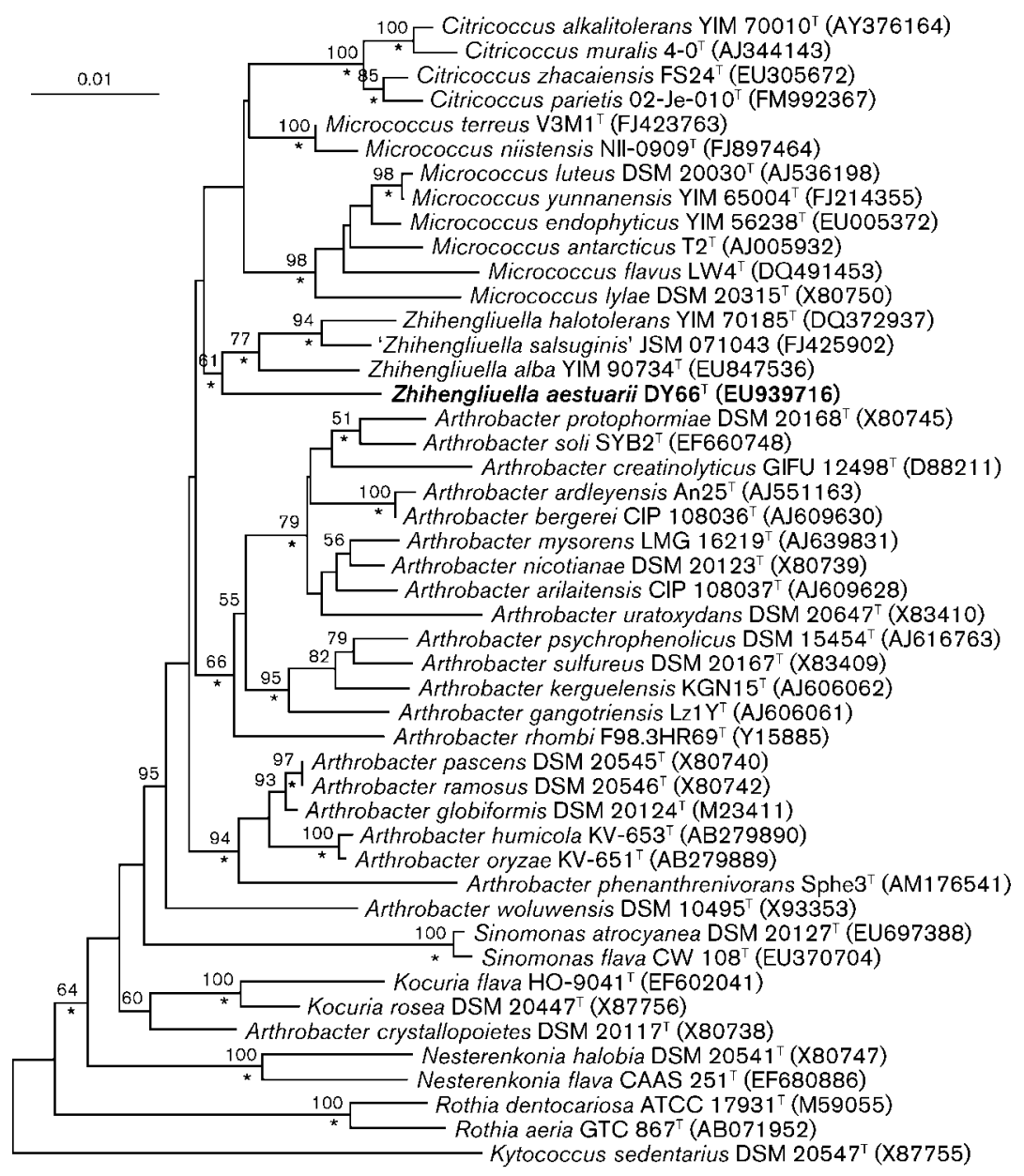

Fig. 1. Neighbour-joining tree based on nearly complete 16S rRNA gene sequences showing relationships between strain DY $66^{\top}$ and closely related recognized species. Percentage bootstrap values ( $>50 \%, 1000$ resamplings) are given at branch points; asterisks indicate that the corresponding nodes (groupings) were also recovered in maximum-parsimony and maximum-likelihood trees. Bar, 0.01 substitutions per nucleotide position. 
except that $\mathrm{NaCl}$ was omitted. The $\mathrm{pH}$ range for growth was determined in TSB containing $2 \% \mathrm{NaCl}$ that was adjusted to $\mathrm{pH} 4-11$ (in increments of $1 \mathrm{pH}$ unit) by the addition of $\mathrm{HCl}$ or $\mathrm{NaOH}$. The temperature optimum and range for growth were tested on TSA containing $2 \% \mathrm{NaCl}$ at $4-50{ }^{\circ} \mathrm{C}$. Anaerobic growth was tested on TSA in a jar containing an AnaeroPack-Anaero (Mitsubishi Gas Chemical), which works as an $\mathrm{O}_{2}$ absorber and $\mathrm{CO}_{2}$ generator, for up to 10 days. Catalase and oxidase activities were determined using 3\%(v/v) hydrogen peroxide and Kovács' reagent (Kovács, 1956), respectively. Nitrate reduction was tested on TSB containing $0.2 \% \mathrm{KNO}_{3}$ (Skerman, 1967). $\mathrm{H}_{2} \mathrm{~S}$ production was determined on Kligler iron agar (Becton Dickinson). Hydrolysis of CMcellulose $(1 \%, \mathrm{w} / \mathrm{v})$, casein $(2 \%$ skimmed milk, w/v), egg yolk $(10 \%, \mathrm{w} / \mathrm{v})$, starch $(0.2 \%, \mathrm{w} / \mathrm{v})$, Tweens 20 and 80 (both $1 \%, \mathrm{w} / \mathrm{v}), \mathrm{L}$-tyrosine $(0.5 \%$, w/v) and xylan $(1 \%$, w/v) was tested as described by Smibert \& Krieg (1994). DNase activity was determined with DNase test agar (Becton Dickinson). Other biochemical tests and enzymic activities were performed using API 20NE and API ZYM kits (bioMérieux) and the GP2 MicroPlate (Biolog) prepared according to the manufacturers' instructions. Antibiotic resistance was determined with the disc diffusion method using commercial antibiotic-impregnated discs (BBL Becton Dickinson). After 5 days of incubation at $30{ }^{\circ} \mathrm{C}$ on TSA, the results were interpreted according to the guidelines set forth by the CLSI (2003).

Cells of strain $\mathrm{DY}_{66^{\mathrm{T}}}$ were Gram-stain-positive, nonspore-forming, non-motile and strictly aerobic. Cells were ovoid to short rod-shaped, approximately $0.7-0.9 \times 0.8-$ $1.1 \mu \mathrm{m}$ after 3 days at $30{ }^{\circ} \mathrm{C}$ on TSA (Supplementary Fig. S3). A rod-coccus life cycle was not displayed. Detailed results of physiological and biochemical analyses are given in Table 1 and the species description. It is evident from Table 1 that there are several phenotypic characters that readily separate strain $\mathrm{DY} 66^{\mathrm{T}}$ from phylogenetically related species.

Cellular fatty acids were prepared (in duplicate) from strain $\mathrm{DY}^{\mathrm{T}}{ }^{\mathrm{T}}$ grown on TSA containing $2 \% \mathrm{NaCl}$ for 2 days at $30{ }^{\circ} \mathrm{C}$ and analysed as methyl esters by GLC according to the instructions of the Microbial Identification System (MIDI). Quantitative analysis of amino acids was performed after derivatization by GC and GC/MS (320-MS Quadrupole; Varian) according to MacKenzie (1987). Determination of the peptidoglycan structure of strain DY66 ${ }^{\mathrm{T}}$ was carried out as described by Schleifer (1985) and Schleifer \& Kandler (1972) with the modification that TLC on cellulose was applied instead of paper chromatography. The cell-wall acyl type was determined by the method of Uchida et al. (1999). Cell-wall sugars were prepared as described by Staneck \& Roberts (1974) and analysed by TLC (silica gel $60 \mathrm{~F}_{254}$; Merck). Seven standard sugars $(0.1 \% \mathrm{w} / \mathrm{v}$; Sigma $)$ and cell-wall hydrolysates of $Z$. halotolerans YIM $70185^{\mathrm{T}}$ and Z. alba YIM $90734^{\mathrm{T}}$ were used as references. Polar lipids were analysed by using
Table 1. Differential phenotypic characteristics of strain DY $66^{\top}$ and related type strains

Strains: 1 , DY66 ${ }^{\mathrm{T}}$; 2, Z. halotolerans YIM $70185^{\mathrm{T}}$; 3, Z. alba YIM 90734 ${ }^{\mathrm{T}}$; 'Z. salsuginis' JSM 071043 (proposed type strain). Data were obtained in this study unless indicated otherwise. +, Positive; -, negative; $\mathrm{W}$, weakly positive.

\begin{tabular}{|c|c|c|c|c|}
\hline Characteristic & 1 & 2 & 3 & 4 \\
\hline $\begin{array}{l}\text { Colony colour on TSA with } \\
2 \% \mathrm{NaCl}\end{array}$ & Yellow & Cream & Cream & Cream \\
\hline \multicolumn{5}{|l|}{$\begin{array}{l}\mathrm{NaCl} \text { concentration for } \\
\text { growth }(\%, w / v)\end{array}$} \\
\hline Range & $0-7$ & $0-25$ & $0-15$ & $0.5-20$ \\
\hline Optimum & 2 & 10 & 5 & $5-10$ \\
\hline \multicolumn{5}{|l|}{ Hydrolysis of: } \\
\hline Casein & + & - & - & + \\
\hline Starch & - & + & - & + \\
\hline Tween 20 & + & + & - & + \\
\hline Tween 80 & - & + & + & + \\
\hline Aesculin & - & + & + & - \\
\hline Gelatin & - & + & + & + \\
\hline \multicolumn{5}{|l|}{ Utilization of (Biolog GP2): } \\
\hline Acetic acid & - & + & - & + \\
\hline$N$-Acetyl-D-galactosamine & - & - & + & - \\
\hline D-Alanine & - & + & - & + \\
\hline L-Alanine & + & - & - & + \\
\hline L-Alanyl glycine & - & + & - & - \\
\hline L-Arabinose & - & + & - & - \\
\hline D-Arabitol & - & + & + & - \\
\hline L-Asparagine & + & - & + & - \\
\hline 2,3-Butanediol & - & + & - & - \\
\hline Cellobiose & - & - & + & + \\
\hline$\beta$-Cyclodextrin & - & + & - & - \\
\hline $2^{\prime}$-Deoxyadenosine & - & - & + & - \\
\hline D-Fructose 6-phosphate & - & + & - & - \\
\hline Gentiobiose & - & + & - & + \\
\hline$\alpha$-D-Glucose 1-phosphate & - & + & - & - \\
\hline D-Glucose 6-phosphate & - & + & - & - \\
\hline L-Glutamic acid & + & + & - & - \\
\hline DL- $\alpha$-Glycerol phosphate & - & + & - & - \\
\hline$\alpha$-Hydroxybutyric acid & - & + & - & + \\
\hline$\beta$-Hydroxybutyric acid & - & + & - & - \\
\hline$\gamma$-Hydroxybutyric acid & - & + & - & + \\
\hline Inosine & - & + & - & - \\
\hline myo-Inositol & - & + & + & - \\
\hline$\alpha$-Ketoglutaric acid & - & + & - & - \\
\hline$\alpha$-Ketovaleric acid & - & + & + & - \\
\hline Lactose & - & - & + & - \\
\hline D-Malic acid & - & + & - & - \\
\hline L-Malic acid & + & + & - & - \\
\hline Maltose & - & + & + & - \\
\hline Maltotriose & - & + & - & + \\
\hline Mannan & - & + & + & - \\
\hline Melibiose & - & + & - & + \\
\hline Methyl $\beta$-D-galactoside & - & + & - & - \\
\hline Methyl $\alpha$-D-glucoside & - & + & + & - \\
\hline Methyl $\beta$-D-glucoside & - & + & - & - \\
\hline Methyl $\alpha$-D-mannoside & - & + & - & - \\
\hline
\end{tabular}


Table 1. cont.

\begin{tabular}{|c|c|c|c|c|}
\hline Characteristic & 1 & 2 & 3 & 4 \\
\hline Palatinose & - & + & + & - \\
\hline L-Pyroglutamic acid & + & - & - & + \\
\hline Pyruvic acid & - & + & - & + \\
\hline Pyruvic acid methyl ester & - & + & - & - \\
\hline D-Psicose & - & + & + & + \\
\hline Salicin & - & + & - & + \\
\hline Sedoheptulosan & - & + & - & + \\
\hline L-Serine & + & - & + & - \\
\hline D-Sorbitol & - & + & - & + \\
\hline Stachyose & - & + & - & - \\
\hline Succinamic acid & - & + & - & - \\
\hline Sucrose & - & + & + & - \\
\hline D-Tagatose & - & + & + & - \\
\hline Thymidine & - & + & + & - \\
\hline $\begin{array}{l}\text { Thymidine } 5^{\prime} \text { - } \\
\text { monophosphate }\end{array}$ & - & + & - & - \\
\hline Trehalose & - & + & + & - \\
\hline Turanose & - & + & - & - \\
\hline Tween 40 & - & + & + & - \\
\hline Tween 80 & - & + & + & - \\
\hline Uridine & - & + & - & + \\
\hline $\begin{array}{l}\text { Uridine } 5^{\prime} \text { - } \\
\text { monophosphate }\end{array}$ & - & + & - & - \\
\hline \multicolumn{5}{|l|}{ Enzyme activity (API ZYM) } \\
\hline Acid phosphatase & - & - & + & - \\
\hline Alkaline phosphatase & - & + & - & + \\
\hline$\alpha$-Chymotrypsin & - & - & + & + \\
\hline Cystine arylamidase & - & - & + & - \\
\hline Esterase lipase (C8) & - & + & + & + \\
\hline$\alpha$-Galactosidase & - & - & + & - \\
\hline$\beta$-Glucosidase & - & - & + & + \\
\hline Lipase (C14) & - & + & - & - \\
\hline Leucine arylamidase & + & - & + & + \\
\hline Valine arylamidase & - & - & + & - \\
\hline Trypsin & $\mathrm{w}$ & - & + & + \\
\hline $\begin{array}{l}\text { Naphthol-AS-BI- } \\
\text { phosphohydrolase }\end{array}$ & $\mathrm{w}$ & - & + & - \\
\hline Esterase (C4) & - & + & + & + \\
\hline Cell-wall sugars ${ }^{\star}$ & Tyv, Glc & $\begin{array}{l}\text { Tyv, } \\
\text { Glc }^{a} \dagger\end{array}$ & $\begin{array}{l}\text { Tyv, } \\
\operatorname{Man}^{b}\end{array}$ & $\begin{array}{l}\text { Tyv, } \\
\operatorname{Man}^{c}\end{array}$ \\
\hline DNA G $+C$ content $(\mathrm{mol} \%)$ & 59.1 & $70.3^{a}$ & $66.5^{b}$ & $67.8^{c}$ \\
\hline
\end{tabular}

${ }^{\star}$ Glc, Glucose; Man, mannose; Tyv, tyvelose.

$\dagger$ Data taken from: $a$, Zhang et al. (2007); b, Tang et al. (2009); $c$, Chen et al. (2010).

standard procedures (Minnikin et al., 1984). Extracted lipids were separated by two-dimensional TLC and identified by spraying with appropriate detection reagents (Minnikin et al., 1984; Komagata \& Suzuki, 1987). Respiratory quinones were extracted (from $300 \mathrm{mg}$ freeze-dried cells) and purified according to the method of Minnikin et al. (1984) and analysed by HPLC as described previously (Kroppenstedt, 1985). For determination of the DNA $\mathrm{G}+\mathrm{C}$ content, DNA was prepared in duplicate and the $\mathrm{G}+\mathrm{C}$ content was determined by the thermal denaturation method of Marmur \& Doty (1962) and calculated using the formula described by Mandel et al. (1970).

The fatty acid profile of strain DY66 ${ }^{\mathrm{T}}$ is shown in Table 2. The predominant fatty acids were anteiso- $\mathrm{C}_{15: 0}(59.5 \%)$ and iso- $\mathrm{C}_{15: 0}(15.8 \%)$, similar to $Z$. halotolerans. The absence of anteiso- $C_{17: 0}$ differentiates strain $D Y 66^{\mathrm{T}}$ from $Z$. halotolerans, $Z$. alba and ' $Z$. salsuginis' (Table 2).

The major menaquinone was MK-10 (71.2\%), and a smaller amount of MK-9 (28.8\%) was present, as for all Zhihengliuella species. The absence of MK-8 and MK-8 $\left(\mathrm{H}_{2}\right)$ as major menaquinones differentiates strain $\mathrm{DY}^{\mathrm{T}}{ }^{\mathrm{T}}$ from Micrococcus species. The total hydrolysate $(4 \mathrm{M} \mathrm{HCl}, 16 \mathrm{~h}$, $100{ }^{\circ} \mathrm{C}$ ) of the peptidoglycan contained the amino acids lysine, glutamic acid and alanine in a molar ratio of about $1.0: 1.8: 2.1$. The peptidoglycan partial hydrolysate (4 M $\mathrm{HCl}, 0.75 \mathrm{~h}, 100{ }^{\circ} \mathrm{C}$ ) contained (in addition to the amino acids) the peptides L-Ala $\rightarrow$ D-Glu, L-Lys $\leftarrow$ L-Ala, L-Lys $\rightarrow$ $\mathrm{D}-\mathrm{Ala}$ and $\mathrm{L}-\mathrm{Ala} \rightarrow \mathrm{L}-\mathrm{Lys} \rightarrow \mathrm{D}-\mathrm{Ala}$, as for all Zhihengliuella species. Dinitrophenylation according to Schleifer (1985) revealed that glutamic acid represents the $\mathrm{N}$ terminus of the interpeptide bridge. Dinitrophenylated alanine was also detected, in smaller amounts. From these data, it was concluded that strain DY $66^{\mathrm{T}}$ shows the peptidoglycan type

Table 2. Cellular fatty acid profiles of strain $D Y 66^{\top}$ and type strains of Zhihengliuella species

Strains: 1 , DY $66^{\mathrm{T}}$; 2, Z. halotolerans YIM $70185^{\mathrm{T}}$; 3, Z. alba YIM $90734^{\mathrm{T}}$; 4, 'Z. salsuginis' JSM 071043. Cells of all strains were harvested after cultivation at $30{ }^{\circ} \mathrm{C}$ on TSA containing $2 \% \mathrm{NaCl}$ for 2 days. Values are mean percentages of total fatty acids from two determinations and were obtained in this study; fatty acids that represented $<0.5 \%$ in all four strains have been omitted. -, Not detected.

\begin{tabular}{|c|c|c|c|c|}
\hline Fatty acid & 1 & 2 & 3 & 4 \\
\hline \multicolumn{5}{|l|}{ Straight-chain } \\
\hline $\mathrm{C}_{14: 0}$ & 1.4 & 1.1 & 1.0 & 1.3 \\
\hline $\mathrm{C}_{16: 0}$ & 6.9 & 5.2 & 5.8 & 7.1 \\
\hline $\mathrm{C}_{18: 0}$ & 5.6 & 1.2 & 2.6 & 2.8 \\
\hline \multicolumn{5}{|l|}{ Branched } \\
\hline iso- $\mathrm{C}_{14: 0}$ & 3.4 & 0.6 & 0.9 & 0.6 \\
\hline iso- $\mathrm{C}_{15: 0}$ & 15.8 & 8.3 & 5.1 & 10.9 \\
\hline iso- $\mathrm{C}_{16: 0}$ & 2.9 & 5.2 & 5.6 & 4.3 \\
\hline iso- $\mathrm{C}_{17: 0}$ & - & 1.2 & 0.8 & 1.2 \\
\hline anteiso- $\mathrm{C}_{13: 0}$ & 0.6 & - & 0.1 & - \\
\hline anteiso- $\mathrm{C}_{15: 0}$ & 59.5 & 61.2 & 63.0 & 57.7 \\
\hline anteiso- $\mathrm{C}_{17: 0}$ & 0.5 & 14.3 & 13.5 & 11.5 \\
\hline \multicolumn{5}{|l|}{ Unsaturated } \\
\hline iso- $\mathrm{C}_{16: 1} \mathrm{H}$ & 0.5 & - & - & - \\
\hline $\mathrm{C}_{18: 1} \omega 7 c$ & 0.9 & - & 0.4 & 0.3 \\
\hline $\mathrm{C}_{18: 1} \omega 9 c$ & 0.8 & - & 0.4 & 0.3 \\
\hline \multicolumn{5}{|l|}{ Hydroxy } \\
\hline $\mathrm{C}_{18: 1} 2-\mathrm{OH}$ & - & 1.7 & 0.5 & 1.7 \\
\hline
\end{tabular}


A $4 \alpha$ (L-Lys $\leftarrow$ L-Ala $\leftarrow$ D-Glu) (Supplementary Fig. S4). The major cell-wall sugars were tyvelose and glucose; a minor amount of galactose was also detected, similar to Zhihengliuella species (Supplementary Fig. S5). Tyvelose is the characteristic sugar of the genus Zhihengliuella, and is not found in strains of the genera Kocuria, Nesterenkonia, Arthrobacter or Micrococcus of the family Micrococcineae (Zhang et al., 2007; Tang et al., 2009). The polar lipid pattern was characterized by the presence of diphosphatidylglycerol, phosphatidylcholine, phosphatidylglycerol, an unknown aminophospholipid and three unknown aminolipids (Supplementary Fig. S6). The DNA G + C content of strain DY66 ${ }^{\mathrm{T}}$ was $59.1 \mathrm{~mol} \%$.

Chemotaxonomic studies indicated that strain $\mathrm{DY} 66^{\mathrm{T}}$ is affiliated with the genus Zhihengliuella. A number of phenotypic characters clearly distinguish strain DY66 ${ }^{\mathrm{T}}$ from phylogenetically related Zhihengliuella species (Table 1). Therefore, strain DY66 ${ }^{\mathrm{T}}$ represents a novel species within the genus Zhihengliuella, for which the name Zhihengliuella aestuarii sp. nov. is proposed.

\section{Description of Zhihengliuella aestuarii sp. nov.}

Zhihengliuella aestuarii (aes.tu.a'ri.i. L. gen. n. aestuarii of a tidal flat, from where the type strain was isolated).

Cells are strictly aerobic, Gram-stain-positive, non-motile, non-spore-forming, ovoids to short rods, approximately $0.7-0.9 \times 0.8-1.1 \mu \mathrm{m}$ after 3 days at $30{ }^{\circ} \mathrm{C}$ on TSA. No rodcoccus life cycle. Catalase-positive and oxidase-negative. Colonies grown on TSA plates for 3 days at $30{ }^{\circ} \mathrm{C}$ are yellow, circular, opaque and convex with entire margins, approximately $1 \mathrm{~mm}$ in diameter. Growth occurs on TSA at 4$37{ }^{\circ} \mathrm{C}$; optimal temperature for growth is $30{ }^{\circ} \mathrm{C}$. The $\mathrm{pH}$ range for growth is 6-10; optimum $\mathrm{pH} 8-9$. Grows in the presence of $0-7 \%(\mathrm{w} / \mathrm{v}) \mathrm{NaCl}$; no growth in the presence of $8 \% \mathrm{NaCl}$. Does not produce $\mathrm{H}_{2} \mathrm{~S}$. Casein is hydrolysed, but CM-cellulose, DNA, egg yolk, Tweens 20 and 80, starch, L-tyrosine and xylan are not. In the API 20NE system (bioMérieux), gives positive results for assimilation of D-glucose and maltose and negative results for nitrate reduction, indole production, D-glucose fermentation, aesculin hydrolysis ( $\beta$-glucosidase), arginine dihydrolase, $\beta$-galactosidase, gelatin hydrolysis, urease and assimilation of $\mathrm{N}$-acetylglucosamine, adipic acid, L-arabinose, capric acid, malic acid, D-mannitol, D-mannose, phenylacetic acid, potassium gluconate and trisodium citrate. In the API ZYM gallery, $\alpha$-glucosidase and leucine arylamidase activities are present and naphthol-AS-BI-phosphohydrolase and trypsin activities are weakly positive; $N$-acetyl- $\beta$-glucosaminidase, acid phosphatase, alkaline phosphatase, $\alpha$-chymotrypsin, cystine arylamidase, esterase (C4), esterase lipase (C8), $\alpha$-fucosidase, $\alpha$-galactosidase, $\beta$-galactosidase, $\beta$-glucosidase, $\beta$-glucuronidase, lipase (C14), $\alpha$-mannosidase and valine arylamidase activities are absent. The following carbon sources are utilized (positive with the Biolog GP2 system): L-alanine, L-asparagine, dextrin, D-fructose, $\alpha$-D-glucose, L-glutamic acid, L-malic acid, D-mannose, D-ribose (weak),
L-pyroglutamic acid (weak), L-serine and D-sorbitol (weak). The remaining substrates of the Biolog GN2 system are not utilized. Cells are sensitive to ( $\mu \mathrm{g}$ per disc, unless otherwise indicated): ampicillin (10), penicillin (10 IU) and vancomycin (30) but resistant to amikacin (30), chloramphenicol (30), erythromycin (15), gentamicin (10), kanamycin (30), nalidixic acid (30), polymyxin B (300 IU), streptomycin (10) and tetracycline (30). Major fatty acids are anteiso$\mathrm{C}_{15: 0}$ and iso- $\mathrm{C}_{15: 0}$. Peptidoglycan type is A4 $\alpha$, L-Lys $\leftarrow$ L-Ala $\leftarrow$ D-Glu. The glycan moiety of the peptidoglycan contains acetyl residues. Major cell-wall sugars are tyvelose and glucose; a minor amount of galactose is also detected. The predominant isoprenoid quinone is MK-10; a minor amount of MK-9 is also detected. The polar lipids are diphosphatidylglycerol, phosphatidylcholine, phosphatidylglycerol, an unknown aminophospholipid and three unknown aminolipids. The DNA G $+\mathrm{C}$ content of the type strain is $59.1 \mathrm{~mol} \%$.

The type strain is strain DY66 ${ }^{\mathrm{T}}\left(=\mathrm{KCTC} 19557^{\mathrm{T}}=\mathrm{JCM}\right.$ $\left.16364^{\mathrm{T}}\right)$, isolated from tidal flat sediment collected from Deukryang Bay, Republic of Korea.

\section{Acknowledgements}

This research was supported by the 21C Frontier Microbial Genomics and Applications Center Program, Ministry of Education, Science \& Technology, Republic of Korea. We are indebted to Dr Peter Schumann (DSMZ, Germany) and KBSI (Suncheon Centre, Korea) for determining peptidoglycan structure and SEM analysis, respectively. The peptidoglycan analysis was carried out by the DSMZ Identification Service.

\section{References}

Chen, Y.-G., Tang, S.-K., Zhang, Y.-Q., Liu, Z.-X., Chen, Q.-H., He, J.-W., Cui, X.-L. \& Li, W.-J. (2010). Zhihengliuella salsuginis sp. nov., a moderately halophilic actinobacterium from a subterranean brine. Extremophiles 14, 397-402.

Chun, J. (1995). Computer-assisted classification and identification of actinomycetes. PhD thesis, University of Newcastle, Newcastle-uponTyne, UK.

Chun, J. \& Goodfellow, M. (1995). A phylogenetic analysis of the genus Nocardia with $16 \mathrm{~S}$ rRNA gene sequences. Int J Syst Bacteriol 45, 240-245.

Chun, J., Lee, J.-H., Jung, Y., Kim, M., Kim, S., Kim, B. K. \& Lim, Y. W. (2007). EzTaxon: a web-based tool for the identification of prokaryotes based on $16 \mathrm{~S}$ ribosomal RNA gene sequences. Int J Syst Evol Microbiol 57, 2259-2261.

CLSI (2003). Performance standards for antimicrobial disk susceptibility tests, 8th edn. Approved Standard M2-A8. Wayne, PA: Clinical and Laboratory Standards Institute.

Felsenstein, J. (1985). Confidence limits on phylogenies: an approach using the bootstrap. Evolution 39, 783-791.

Felsenstein, J. (1993). PHYLIP (phylogeny inference package), version 3.5c. Distributed by the author. Department of Genome Sciences, University of Washington, Seattle, USA.

Fitch, W. M. (1971). Toward defining the course of evolution: minimum change for a specific tree topology. Syst Zool 20, 406-416. 
Jukes, T. H. \& Cantor, C. R. (1969). Evolution of protein molecules. In Mammalian Protein Metabolism, vol. 3, pp. 21-132. Edited by H. N. Munro. New York: Academic Press.

Komagata, K. \& Suzuki, K. (1987). Lipids and cell-wall analysis in bacterial systematics. Methods Microbiol 19, 161-207.

Kovács, N. (1956). Identification of Pseudomonas pyocyanea by the oxidase reaction. Nature 178, 703.

Kroppenstedt, R. M. (1985). Fatty acid and menaquinone analysis of actinomycetes and related organisms. In Chemical Methods in Bacterial Systematics, pp. 173-199. Edited by M. Goodfellow \& D. E. Minnikin. London: Academic Press.

MacKenzie, S. L. (1987). Gas chromatographic analysis of amino acids as the $N$-heptafluorobutyryl isobutyl esters. J Assoc Off Anal Chem 70, 151-160.

Mandel, M., Igambi, L., Bergendahl, J., Dodson, M. L., Jr \& Scheltgen, E. (1970). Correlation of melting temperature and cesium chloride buoyant density of bacterial deoxyribonucleic acid. J Bacteriol 101, $333-338$.

Marmur, J. \& Doty, P. (1962). Determination of the base composition of deoxyribonucleic acid from its thermal denaturation temperature. J Mol Biol 5, 109-118.

Minnikin, D. E., O'Donnell, A. G., Goodfellow, M., Alderson, G., Athayle, M., Schaal, A. \& Parlett, J. H. (1984). An integrated procedure for the extraction of bacterial isoprenoid quinones and polar lipids. J Microbiol Methods 2, 233-241.

Saitou, N. \& Nei, M. (1987). The neighbor-joining method: a new method for reconstructing phylogenetic trees. Mol Biol Evol 4, 406-425.

Schleifer, K. H. (1985). Analysis of the chemical composition and primary structure of murein. Methods Microbiol 18, 123-156.
Schleifer, K. H. \& Kandler, O. (1972). Peptidoglycan types of bacterial cell walls and their taxonomic implications. Bacteriol Rev 36, 407477.

Skerman, V. B. D. (1967). A Guide to the Identification of the Genera of Bacteria, 2nd edn. Baltimore: Williams \& Wilkins.

Smibert, R. M. \& Krieg, N. R. (1994). General characterization. In Methods for General and Molecular Bacteriology, pp. 607-654. Edited by P. Gerhardt, R. G. E. Murray, W. A. Wood \& N. R. Krieg. Washington, DC: American Society for Microbiology.

Staneck, J. L. \& Roberts, G. D. (1974). Simplified approach to identification of aerobic actinomycetes by thin-layer chromatography. Appl Microbiol 28, 226-231.

Swofford, D. L. (1998). PAUP ${ }^{*}$ - Phylogenetic Analysis Using Parsimony ( ${ }^{*}$ and other methods), version 4.0. Sunderland, MA: Sinauer Associates.

Tang, S. K., Wang, Y., Chen, Y., Lou, K., Cao, L.-L., Xu, L.-H. \& Li, W.-J. (2009). Zhihengliuella alba sp. nov., and emended description of the genus Zhihengliuella. Int J Syst Evol Microbiol 59, 2025-2031.

Thompson, J. D., Gibson, T. J., Plewniak, F., Jeanmougin, F. \& Higgins, D. G. (1997). The CLUSTAL_X windows interface: flexible strategies for multiple sequence alignment aided by quality analysis tools. Nucleic Acids Res 25, 4876-4882.

Uchida, K., Kudo, T., Suzuki, K. I. \& Nakase, T. (1999). A new rapid method of glycolate test by diethyl ether extraction, which is applicable to a small amount of bacterial cells of less than one milligram. J Gen Appl Microbiol 45, 49-56.

Zhang, Y. Q., Schumann, P., Yu, L. Y., Liu, H. Y., Zhang, Y. Q., Xu, L. H., Stackebrandt, E., Jiang, C. L. \& Li, W. J. (2007). Zhihengliuella halotolerans gen. nov., sp. nov., a novel member of the family Micrococcaceae. Int J Syst Evol Microbiol 57, 1018-1023. 